\title{
The effects of ionic strength on the toxicity of aluminium to Atlantic salmon (Salmo salar) under non-steady state chemical conditions
} \author{
Leif Asbjørn VØLLESTAD ${ }^{1)}$ and Antonio B.S. POLÉO ${ }^{1) *}$ \\ Norwegian Institute for Water Research, P.O. Box 173, Kjelsås, N-0411, Oslo, Norway. \\ ${ }^{1)}$ Department of Biology, University of Oslo, P.O. Box 1066, Blindern, N-0316, Oslo, Norway \\ *e-mail corresponding author: toni.poleo@bio.uio.no
}

Espen LYDERSEN, Sigurd ØXNEVAD ${ }^{1)}$, Kjartan ØSTBYE ${ }^{1)}$, Ronny A. ANDERSEN ${ }^{1)}$, Frode BJERKELY ${ }^{1)}$,

\begin{abstract}
We have tested the influence of water ionic strength on the toxicity of aluminium in fish by comparing the mortality of Atlantic salmon (Salmo salar) parr exposed to Al-rich water with additions of $\mathrm{Ca}^{2+}$ or $\mathrm{Na}^{+}$. The fish were exposed in parallel to Al-rich water (Al $\left.500 \mu \mathrm{g} t^{-1}, p H 5.8\right)$ under non-steady state conditions, with and without the addition of one of the two base cations. The amount of $\mathrm{Na}^{+}$and $\mathrm{Ca}^{2+}$ added to the water was calculated in order to obtain an identical increase in water ionic strength. Fish mortality was dependent on water residence time and whether or not base cations were added to the Al-rich water. In all Al-exposures, the highest mortality was always observed in fish exposed to water with the shortest residence time. Mortality decreased systematically with increasing water residence time through the exposure set-up. The addition of a base cation, $\mathrm{Ca}^{2+}$ or $\mathrm{Na}^{+}$, to the Al-rich water reduced fish mortality significantly compared to the Al-only exposures. Furthermore, increasing ionic strength with $\mathrm{Na}^{+}$reduced mortality to a larger extent than the corresponding increase in ionic strength by the addition of $\mathrm{Ca}^{2+}$. The variation in mortality between the various aluminium and base cation treatments is discussed in terms of aluminium chemistry, specific mitigating effects of $\mathrm{Ca}^{2+}$ and $\mathrm{Na}^{+}$, and the general importance of water ionic strength. This study clearly demonstrates that $\mathrm{Ca}^{2+}$ does not play an unique role as an ameliorating cation for Al-toxicity in fish under non-steady state chemical conditions. Thus, ionic strength seems to be important, probably for the interaction between aluminium and the gill surface, reducing the possibility for positively charged aluminium species to bind to negatively charged sites.
\end{abstract}

Key words: acidification, aluminium toxicity, fish, Atlantic salmon, ionic strength

\section{INTRODUCTION}

One of the most important consequences of the acidification of soil water systems is the mobilisation of aluminium from the edaphic to the aquatic environment (Cronan \& Schofield 1979; Seip et al. 1989). Aqueous aluminium is recognised by many authors as the principal toxicant killing fish in acidified waters (Burrows 1977; Driscoll et al. 1980; Howells et al. 1994; Gensemer \& Playle 1999). Aluminium primarily leaches out from soils with low $\mathrm{pH}$-buffering capacity, i.e. low dissolution rates of base cations. Such acid sensitive catchments are characterised by slowly weatherable soils and rocks, often with only a thin soil cover. Within these catchments, the soil water and runoff concentration of terrestrial derived base cations, like $\mathrm{Ca}^{2+}$ and $\mathrm{Mg}^{2+}$, are normally low. Furthermore, acidification is responsible for the depletion of base cations from the soil complex and runoff (Kirchner \& Lydersen 1995, Likens et al. 1996). Accordingly, it has repeatedly been observed that the negative impacts of acidification on freshwater fish are most severe in low conductivity (i.e. low ionic strength) waters (Bua \& Snekvik 1972; Leivestad et al. 1980; Muniz 1984; Hutchinson et al. 1989; Bulger et al.1993).

$\mathrm{Ca}^{2+}$ is the predominant cation in most natural waters, and the concentration of $\mathrm{Ca}^{2+}$ is positively cor- related with ionic strength. It is well documented that high concentrations of $\mathrm{Ca}^{2+}$ can reduce Al-toxicity in fish (Brown 1981, 1983; Playle et al. 1989). This mitigating effect has most often been attributed to $\mathrm{Ca}^{2+}$ per se, through its effect on fish gill permeability. This is not surprising since $\mathrm{Ca}^{2+}$ is important in stabilising biological membranes, maintaining the integrity of cell to cell junctions, and controlling ion and water permeability across epithelial tissues (Schoffeniels 1967; Oduleye 1975; Steen \& Stray-Pedersen 1975; McDonald 1983). In accordance to this, early field survey investigations of acidic lakes in southernmost Norway indicated that the concentration of $\mathrm{Ca}^{2+}$ in the water was of the same importance for the fish population status as $\mathrm{pH}$ (Wright \& Snekvik 1978). Later, however, correspondent surveys indicate no correlation between water $\mathrm{Ca}^{2+}$ and fish population status (Muniz \& Walløe 1990; Baker et al. 1993). It is therefore possible that the mitigating effects of $\mathrm{Ca}^{2+}$, and base cations in general, to some extent can be explained by the water ionic strength (Lydersen et al. 2002). The importance of ionic strength was not tested in any of the field surveys mentioned above.

The reason to believe that ionic strength is important for the Al-toxicity in fish, is that the interaction between aqueous aluminium and the gill surface is central for the mechanism of acute Al-toxicity in fish (Exley et al. 1991, 1996; Poléo 1995; Poléo \& Bjerkely 2000). The ionic strength $(I)$ is defined as: 


$$
I=0.5 \Sigma c_{i} z_{i}^{2}
$$

$\left(c_{i}\right)$ is the molar concentration and $\left(z_{i}\right)$ the charge of an ion $(i)$, and the sum is taken over all ions in the solution. Ionic binding is probably of major importance for the interaction between aluminium and the gill surface, and there are two main reasons to anticipate that the ionic strength could affect the interaction between them (Lydersen et al. 2002). The first reason is that cations may compete for the negatively charged sites on the gill surface. The second reason is that increased ionic strength will reduce the rate of ionic binding between opposite charged molecules (Atkins 1982), because of enhanced competition between anions and the negatively charged gill surface for the cationic Al-species. In other words, the layer above a surface in which dissolved ions can be influenced by its charge is dependent on ionic strength (Chu 1967). In a medium of low ionic strength, this layer will extend further into the solution than in a medium of higher ionic strength. Due to this, the availability of monomeric inorganic Al-species that can bind to the gill surface by ionic bonds is higher in low ionic strength water than in high ionic strength water (Lydersen et al. 2002).

Thus, increased ionic strength may reduce Al-toxicity both by reducing the ability of aluminium to bind to the gill by ionic bonds, and by competition between base cations and positively charged aluminium for negatively charged sites on the gill surface (Lydersen et al. 2002). According to this, it has been indicated that not only calcium, but also high water $\mathrm{Na}^{+}$-concentrations may reduce Al-toxicity in fish (Brown 1981; Dietrich et al. 1989).

Present understanding of the effect of aluminium in natural waters and its interactions with aquatic biota is based largely upon chemical equilibrium constants. The environment, however, and in particular the biological environment, is not in steady state. Accordingly, true chemical equilibrium is seldom approached in natural systems like surface waters, and some ecotoxicological studies have indicated that a non-steady state Al-chemistry can predominate in these systems (Weatherley et al. 1991; Rosseland et al. 1992; Lydersen et al. 1994; Poléo et al. 1994). The same studies also indicate that a non-steady state transient Al-chemistry may dictate the Al-toxicity to fish in acidified freshwater systems. In the present study we have therefore investigated the possible effect of ionic strength on the toxicity of aluminium under non-steady state chemical conditions. We test the prediction that an equal increase in ionic strength, by the addition of $\mathrm{Ca}^{2+}$ and $\mathrm{Na}^{+}$respectively, will reduce the Al-toxicity to the same extent.

\section{METHODS}

\subsection{Experimental animals}

One year old Atlantic salmon (Salmo salar) parr, 5.4 $\pm 0.6 \mathrm{~cm}$ and $1.7 \pm 0.1 \mathrm{~g}$, were obtained from a local hatchery near Oslo. The experimental fish were brought into the fish holding department at the University of Oslo, where they were kept and acclimatised for two weeks prior to the experiments. The fish holding department receives dechlorinated Oslo tap water (Tab. 1).

Tab. 1. Major water quality parameters of the water in the fish holding department at University of Oslo measured during the experimental period. *Conductivity was measured at ambient temperature (4.8 $\left.6.1^{\circ} \mathrm{C}\right)$.

\begin{tabular}{lccc}
\hline Parameter & & mean \pm s.d. & $\mathrm{N}$ \\
\hline $\mathrm{pH}$ & & $6.5 \pm 0.1$ & 28 \\
$\mathrm{Conductivity}^{*}$ & $\mu \mathrm{S} \mathrm{cm}^{-1}$ & $19.7 \pm 0.8$ & 28 \\
$\mathrm{Ca}^{2+}$ & $\mathrm{mg} \mathrm{l}^{-1}$ & $3.11 \pm 0.07$ & 6 \\
$\mathrm{Na}^{+}$ & $\mathrm{mg} \mathrm{l}^{-1}$ & $2.14 \pm 0.05$ & 6 \\
$\mathrm{Mg}^{2+}$ & $\mathrm{mg} \mathrm{l}^{-1}$ & $0.54 \pm 0.01$ & 8 \\
$\mathrm{~K}^{+}$ & $\mathrm{mg} \mathrm{l}^{-1}$ & $0.36 \pm 0.01$ & 8 \\
$\mathrm{Cl}^{-}$ & $\mathrm{mg} \mathrm{l}^{-1}$ & $2.63 \pm 0.15$ & 4 \\
$\mathrm{NO}_{3}{ }^{-}$ & $\mu \mathrm{g} \mathrm{l}^{-1}$ & 275 & 2 \\
$\mathrm{SO}_{4}{ }^{2-}$ & $\mathrm{mg} \mathrm{l}^{-1}$ & $6.00 \pm 0.49$ & 8 \\
$\mathrm{TOC}^{-1}$ & $\mathrm{mg} \mathrm{l}^{-1}$ & $3.19 \pm 0.31$ & 8 \\
\hline
\end{tabular}

\subsection{Test conditions}

The experiments were performed in the laboratory of the fish holding department at the University. We used a flow-through exposure system for the experiments (Fig. 1), consisting of three channels $(218 \mathrm{~cm}$ long, $42 \mathrm{~cm}$ wide, and $16 \mathrm{~cm}$ deep). Each channel was divided into 5 chambers in which the fish were exposed. The water flow rate into the channels was approximately 3.01 $\mathrm{min}^{-1}$, and the water residence time through each channel was about $20 \mathrm{~min}$. The water was well aerated on its way through the channels, and the water flow of 3.01 $\mathrm{min}^{-1}$ provided at least 5.01 of water per gram of fish per day. This is well above $2.01 \mathrm{~g}^{-1}$ day $^{-1}$ which is recommended for this kind of experiments (Sprague 1973). The fish were sheltered by covers over the channels.

In two of the channels, dynamic Al-chemistry conditions were prepared by addition of an acidic Al-stock solution to the department water at the inlet of the channels (Fig. 1). The Al-stock solution was prepared by dissolving $\mathrm{Al}\left(\mathrm{NO}_{3}\right)_{3} \times 9 \mathrm{H}_{2} \mathrm{O}$, and $\mathrm{HNO}_{3}$ in distilled water. The $\mathrm{pH}$ of this stock solution was kept low $(\mathrm{pH}$ 2.0 ) in order to ensure that the total amount of $\mathrm{Al}$ was present as $\mathrm{Al}^{3+}$ before it was added to the department water. The fish were exposed to a dynamic Al-chemistry because the $\mathrm{pH}(2.0)$ of the Al-stock solution was rapidly risen to 5.8 , as this solution was mixed with the approximately neutral department water $(\mathrm{pH} 6.5)$. The nominal Al-concentration was about $500 \mu \mathrm{g} \mathrm{l^{-1 }}$ (18.5 $\mu \mathrm{M})$. Depending on the experiment, we also added base cation solutions, either $\mathrm{Ca}^{2+}$ or $\mathrm{Na}^{+}$, to the experimental water (Fig. 1). We used chloride salts of the base cations to prepare the base cation solutions. The amount of $\mathrm{Na}^{+}$ added to the experimental water was calculated in order to obtain an identical ionic strength increase corre- 


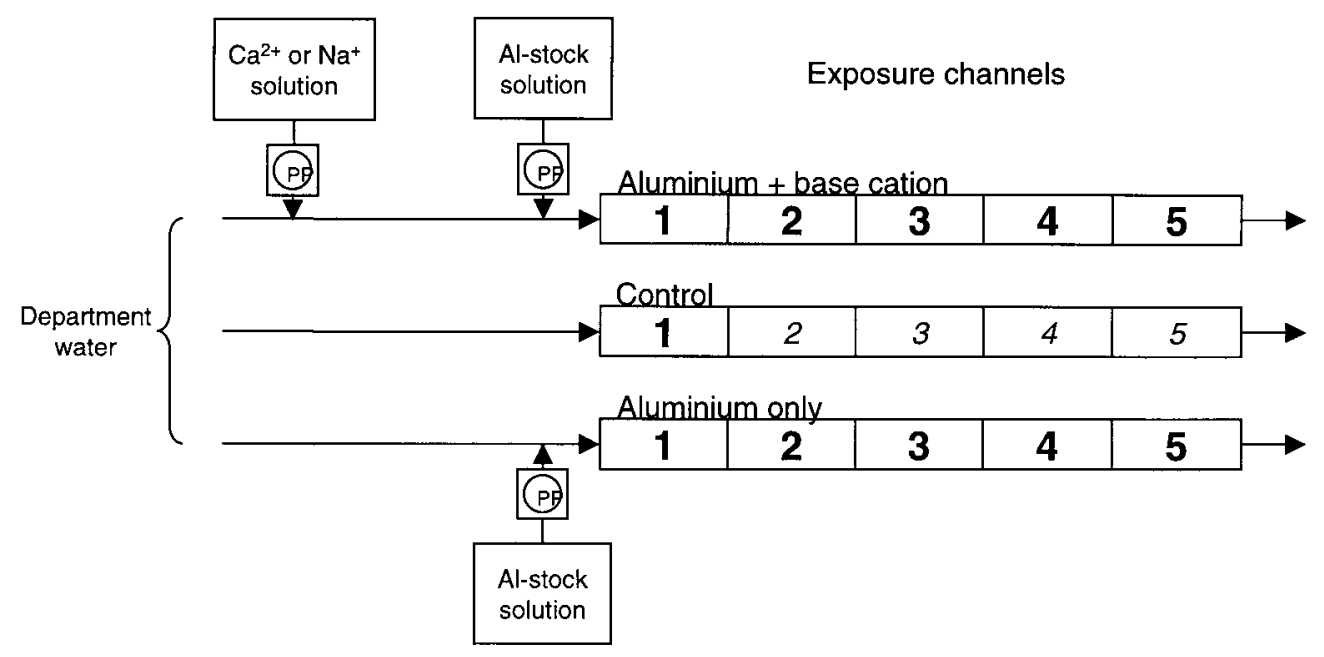

Fig. 1. A schematic presentation of the flow-through exposure system used in the experiments. Three exposure channels were divided into five chambers (1-5) in which the fish were exposed. Aluminium and base cation solutions were added to the department water by means of peristaltic pumps (PP). The water residence time after the addition of aluminium to the department water was 1,5 , 10,15 and $20 \mathrm{~min}$ in chamber $1-5$ respectively.

sponding to an addition of $2 \mathrm{mg} \mathrm{Ca}{ }^{2+} \mathrm{l}^{-1}$. The third experimental channel always acted as control, receiving only untreated department water (Tab. 1). Water temperature varied between 4.8 and $6.1{ }^{\circ} \mathrm{C}$ during the experimental period.

\subsection{Experimental protocol}

The present study was performed as two experiments, each carried out for $140 \mathrm{~h}$. The fish were exposed in parallel to; dynamic Al-chemistry medium with addition of a base cation $\left(\mathrm{Ca}^{2+}\right.$ in the first experiment and $\mathrm{Na}^{+}$in the second), dynamic Al-chemistry medium only, and untreated department water. We used approximately 25 fish in each of the 5 exposure chambers within each of the two Al-chemistry channels. In the control channel, however, we used only 10 fish in the first chamber. The fish were always introduced into the channels one day before the start of the experiments.

Each exposure chamber was examined for dead fish at least once a day. Fish were judged to be dead when opercular movements had ceased and no swimming response could be elicited by stimulation of the caudal peduncle. Water temperature, conductivity, and $\mathrm{pH}$ were measured daily throughout the experiments. The chemical dosages and water flow into each channel were also controlled every day. Three or four times during each experiment, in situ aluminium fractionations and analyses were conducted. Water samples for later analyses of all major ions were collected.

\subsection{Water chemistry analyses}

Water $\mathrm{pH}$ was measured using a Radiometer PHM80 with a Radiometer GK-2401C combined glass-elec- trode. The $\mathrm{pH}$ readings were taken when the $\mathrm{pH}$-meter drifted less than $0.01 \mathrm{pH}$ unit per minute. The standard deviation of the measured $\mathrm{pH}$ was $\pm 0.01 \mathrm{pH}$ unit. The conductivity was measured with a Radiometer CDM- 80 . The conductivity was read when three consecutive measurements were identical within one tenth of a unit $\left(\mu \mathrm{S} \mathrm{cm}^{-1}\right)$. The $\mathrm{pH}$ and conductivity measurements, as well as Al-fractionations were performed immediately after the water samples were taken. Aqueous aluminium was fractionated by the extraction technique described by Barnes (1975), combined with the cation exchange procedure described by Driscoll (1984), following Lydersen et al. (1990). The aluminium concentration in the various fractions was measured by a Shimadzu UV1201 spectrophotometer at $395 \mathrm{~nm}$. Absorbance was also measured at $600 \mathrm{~nm}$ in order to correct for iron interference (Sullivan et al. 1986).

$\mathrm{Na}^{+}, \mathrm{K}^{+}, \mathrm{Ca}^{2+}$ and $\mathrm{Mg}^{2+}$ were analysed by Atomic Absorption Spectroscopy (AAS), $\mathrm{SO}_{4}{ }^{2-}$ and $\mathrm{Cl}^{-}$by ion chromatography (IC), $\mathrm{NO}_{3}^{-}$by the indophenolblue method and total organic carbon (TOC) by a combined photochemical (UV) wet-chemical $\left(\mathrm{S}_{2} \mathrm{O}_{8}{ }^{2-}\right)$ oxidation method.

\subsection{Survival analyses}

Survival Analysis (StatView 4.5, see Abacus Concepts 1994) was used to analyse the survival data. Survival Analysis handles data in which the variable of interest is the time taken for a certain event to occur (Fox $1993)$; in this case the time from the fish were placed in the experimental channels until death. Surviving fish were censored. This was the particular reason for using this analytical technique since the experiments were not driven until $100 \%$ mortality in all groups. 
Tab. 2. Mean ( \pm s.d.) $\mathrm{pH}$, ionic strength $\left(10^{-4} \mathrm{M}\right)$, and concentration of various Al-fractions $\left(\mu \mathrm{g} 1^{-1}\right)$ in the experimental waters. $\mathrm{N}=3$ for each chamber, while $\mathrm{N}=15$ for the control exposures. $\mathrm{Al}_{\mathrm{r}}=$ total amount of aluminium, $\mathrm{Al}_{\mathrm{c}}=$ colloidal aluminium, $\mathrm{Al}_{\mathrm{o}}=$ organic monomeric aluminium, and $\mathrm{Al}_{\mathrm{i}}=$ inorganic monomeric aluminium.

\begin{tabular}{|c|c|c|c|c|c|c|c|}
\hline Exposure & Chamber & $\mathrm{pH}$ & Ionic strength & $\mathrm{Al}_{\mathrm{r}}$ & $\mathrm{Al}_{\mathrm{c}}$ & $\mathrm{Al}_{\mathrm{o}}$ & $\mathrm{Al}_{\mathrm{i}}$ \\
\hline \multicolumn{8}{|c|}{ Experiment 1} \\
\hline Al-only & $\begin{array}{l}1 \\
2 \\
3 \\
4 \\
5\end{array}$ & $\begin{array}{l}5.76 \pm 0.06 \\
5.75 \pm 0.07 \\
5.75 \pm 0.07 \\
5.74 \pm 0.07 \\
5.74 \pm 0.07\end{array}$ & $\begin{array}{l}4.77 \pm 0.01 \\
4.77 \pm 0.02 \\
4.76 \pm 0.01 \\
4.76 \pm 0.01 \\
4.76 \pm 0.01\end{array}$ & $\begin{array}{l}570 \pm 46 \\
608 \pm 47 \\
587 \pm 80 \\
609 \pm 39 \\
592 \pm 10\end{array}$ & $\begin{array}{l}111 \pm 38 \\
158 \pm 28 \\
160 \pm 55 \\
202 \pm 23 \\
195 \pm 38\end{array}$ & $\begin{array}{c}137 \pm 15 \\
163 \pm 7 \\
160 \pm 8 \\
165 \pm 12 \\
168 \pm 14\end{array}$ & $\begin{array}{c}321 \pm 43 \\
287 \pm 44 \\
266 \pm 28 \\
242 \pm 9 \\
230 \pm 15\end{array}$ \\
\hline $\mathrm{Al}+\mathrm{Ca}$ & $\begin{array}{l}1 \\
2 \\
3 \\
4 \\
5\end{array}$ & $\begin{array}{l}5.83 \pm 0.09 \\
5.83 \pm 0.05 \\
5.83 \pm 0.05 \\
5.84 \pm 0.05 \\
5.84 \pm 0.05\end{array}$ & $\begin{array}{l}6.20 \pm 0.20 \\
6.28 \pm 0.05 \\
6.28 \pm 0.05 \\
6.28 \pm 0.05 \\
6.28 \pm 0.05\end{array}$ & $\begin{array}{l}497 \pm 47 \\
510 \pm 29 \\
561 \pm 59 \\
526 \pm 29 \\
512 \pm 49\end{array}$ & $\begin{array}{l}120 \pm 13 \\
157 \pm 16 \\
221 \pm 13 \\
199 \pm 17 \\
180 \pm 30\end{array}$ & $\begin{array}{c}131 \pm 20 \\
141 \pm 15 \\
146 \pm 9 \\
147 \pm 10 \\
158 \pm 16\end{array}$ & $\begin{array}{l}246 \pm 60 \\
212 \pm 42 \\
193 \pm 54 \\
180 \pm 27 \\
174 \pm 23\end{array}$ \\
\hline Control & & $6.51 \pm 0.02$ & $4.71 \pm 0.01$ & $57 \pm 4$ & $39 \pm 4$ & $23 \pm 7$ & 0 \\
\hline \multicolumn{8}{|c|}{ Experiment 2} \\
\hline Al-only & $\begin{array}{l}1 \\
2 \\
3 \\
4 \\
5\end{array}$ & $\begin{array}{l}5.79 \pm 0.15 \\
5.78 \pm 0.16 \\
5.76 \pm 0.15 \\
5.79 \pm 0.06 \\
5.78 \pm 0.16\end{array}$ & $\begin{array}{l}4.49 \pm 0.01 \\
4.49 \pm 0.01 \\
4.49 \pm 0.01 \\
4.49 \pm 0.01 \\
4.49 \pm 0.01\end{array}$ & $\begin{array}{c}520 \pm 43 \\
604 \pm 75 \\
614 \pm 111 \\
564 \pm 32 \\
562 \pm 16\end{array}$ & $\begin{array}{c}132 \pm 21 \\
225 \pm 85 \\
240 \pm 114 \\
215 \pm 44 \\
213 \pm 29\end{array}$ & $\begin{array}{c}130 \pm 20 \\
150 \pm 15 \\
158 \pm 16 \\
157 \pm 7 \\
160 \pm 14\end{array}$ & $\begin{array}{l}258 \pm 14 \\
229 \pm 21 \\
216 \pm 23 \\
192 \pm 12 \\
190 \pm 12\end{array}$ \\
\hline $\mathrm{Al}+\mathrm{Na}$ & $\begin{array}{l}1 \\
2 \\
3 \\
4 \\
5\end{array}$ & $\begin{array}{l}5.71 \pm 0.06 \\
5.72 \pm 0.02 \\
5.73 \pm 0.02 \\
5.73 \pm 0.02 \\
5.73 \pm 0.02\end{array}$ & $\begin{array}{l}6.23 \pm 0.13 \\
6.23 \pm 0.13 \\
6.24 \pm 0.13 \\
6.23 \pm 0.13 \\
6.23 \pm 0.13\end{array}$ & $\begin{array}{c}537 \pm 20 \\
614 \pm 62 \\
622 \pm 101 \\
632 \pm 92 \\
595 \pm 70\end{array}$ & $\begin{array}{l}137 \pm 24 \\
222 \pm 68 \\
248 \pm 74 \\
231 \pm 84 \\
225 \pm 72\end{array}$ & $\begin{array}{c}134 \pm 7 \\
149 \pm 14 \\
155 \pm 12 \\
157 \pm 12 \\
158 \pm 14\end{array}$ & $\begin{array}{l}267 \pm 46 \\
244 \pm 20 \\
259 \pm 34 \\
244 \pm 19 \\
212 \pm 15\end{array}$ \\
\hline Control & & $6.46 \pm 0.03$ & $4.39 \pm 0.01$ & $96 \pm 2$ & $36 \pm 22$ & $31 \pm 16$ & $28 \pm 13$ \\
\hline
\end{tabular}

In the survival analysis the hazard function $l(t)$ : denotes the probability that an individual survives until time $t+1$, given that it has survived to time $t$. For any covariate $Z$, it is assumed that the hazard can be expressed as the baseline hazard $(Z=0)$ multiplied by an exponential function of $Z ; l(t ; Z)=1_{0}(t) \times \mathrm{e}^{\beta Z}$. In the parametric Weibull model, it is assumed that the hazard function is either strictly increasing, strictly decreasing, or constant (i.e. the assumption of any specific form of the hazard function is relaxed). We used the Weibull model to compare survival times in fish exposed to Alrich medium with increased ionic strength and in fish exposed to Al-rich medium only. Chamber number (i.e. the age of the mixed acidic water) influences mortality, and we therefore used chamber number as another factor in the analysis. Differences between exposures, and between chambers, were evaluated using a Wald $\chi^{2}$-test, and differences in hazard are quantified using $\mathrm{e}^{\beta}$. If the survival probabilities are not different between groups, the $\mathrm{e}^{\beta}$ will not be significantly different from 1 . Low $\mathrm{e}^{\beta}$, however, implies a low survival probability relative to the group with the highest survival in the experiment.

\section{RESULTS}

\subsection{Water chemistry}

The addition of chemicals to the department water altered the chemical composition of the experimental water. $\mathrm{pH}$ was lowered from 6.5 to between 5.7 and 5.9 in the Al-exposure channels (Tab. 2). In the calcium exposure, $\mathrm{Ca}^{2+}$ increased from 3.11 to $5.07 \mathrm{mg} \mathrm{l}^{-1}$, while $\mathrm{Na}^{+}$increased from 2.14 to $5.44 \mathrm{mg} \mathrm{l}^{-1}$ in the sodium exposure. These increases, together with a corresponding increase in $\mathrm{Cl}^{-}$concentration, resulted in an increase in ionic strength from between 4.5 and $4.810^{-4} \mathrm{M}$ to between 6.2 and $6.310^{-4} \mathrm{M}$.

The total amount of aluminium $\left(\mathrm{Al}_{\mathrm{r}}\right)$ in the Al-solutions increased from between 57 and $96{\mu \mathrm{g} \mathrm{l}^{-1}}$, to between 497 and $632 \mu \mathrm{g} \mathrm{l}^{-1}$ (Tab. 2). The Al-analyses revealed that the various Al-fractions changed as the water passed through the experimental channels. The concentration of colloidal aluminium $\left(\mathrm{Al}_{\mathrm{c}}\right)$ and organic monomeric aluminium $\left(\mathrm{Al}_{\mathrm{o}}\right)$ increased systematically through the channels, while the concentration of inorganic monomeric aluminium $\left(\mathrm{Al}_{\mathrm{i}}\right)$ showed a correspondent systematic decrease. Even though the concentration of $\mathrm{Al}_{\mathrm{r}}$ varied between the exposure chambers, we found no systematic changes in this fraction through the channels (Tab. 2).

We observed that the $\mathrm{Al}_{0}$-fraction in the $\mathrm{Al}$-enriched waters was much higher than in the untreated control water. The total organic pool in the natural water may have a proportion of non-complexed organic molecules that represent a sink for binding of additional aluminium. A non-complexed organic pool like this could therefore, to some extent, contribute to the increase in 


\section{Experiment 1}

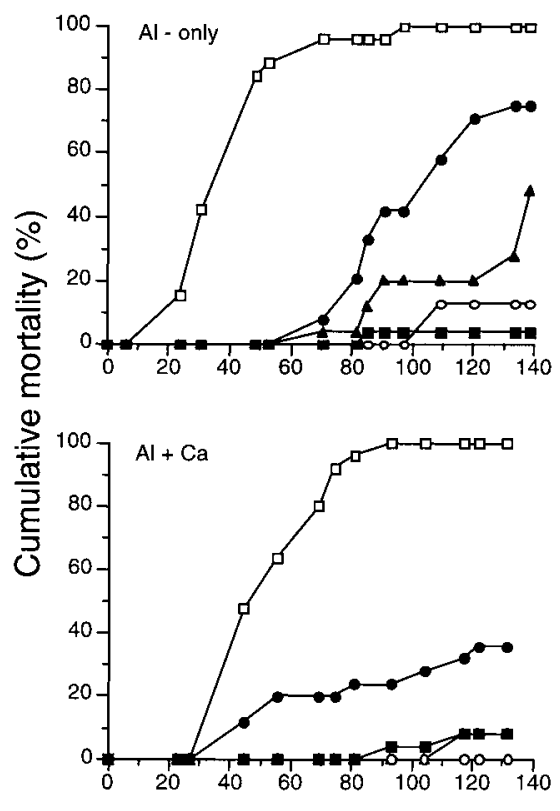

Experiment 2
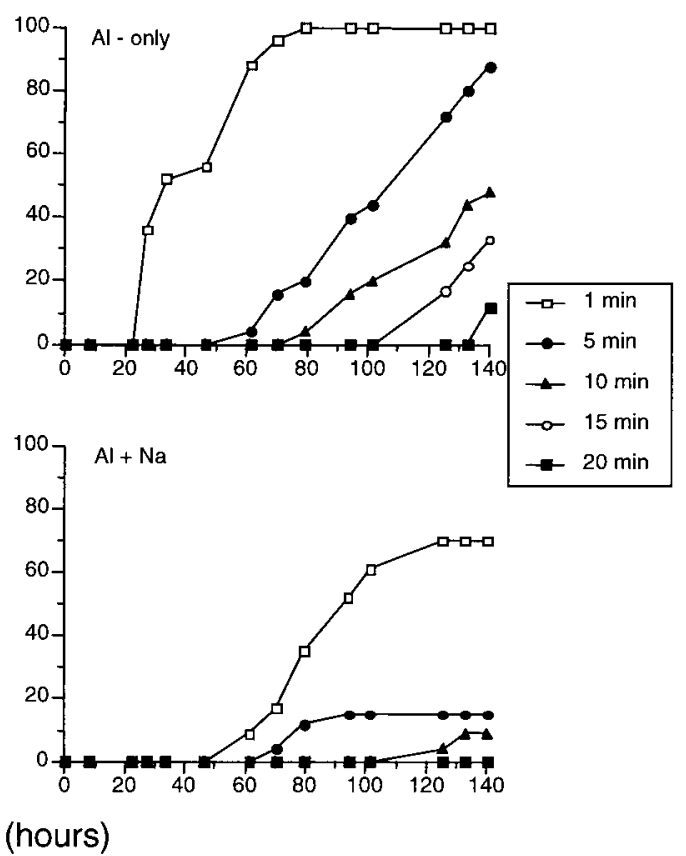

Fig. 2. Cumulative mortality of Atlantic salmon exposed to various combinations of aluminium and base cations. For each combination, fish were exposed to the water at 5 different residence times after the addition of aluminium to the department water: 1 , $5,10,15$ and $20 \mathrm{~min}$.

$\mathrm{Al}_{\mathrm{o}}$. In the present study, however, we used an acidic $\mathrm{Al}\left(\mathrm{NO}_{3}\right)_{3}$-stock solution ( $\mathrm{pH}$ about 2.0) to prepare the dynamic Al-chemistry conditions. In this acidic solution the octahedral hexahydrate $\mathrm{Al}\left(\mathrm{H}_{2} \mathrm{O}\right)_{6}{ }^{3+}$ (often written as $\mathrm{Al}^{3+}$ ) should be the only significant $\mathrm{Al}$-species present (Hem \& Roberson 1967; Lydersen 1990). According to Hem \& Roberson (1967) and Lydersen et al. (1990), aluminium starts to polymerise as soon as $\mathrm{pH}$ is raised to above $4.0-4.5$, depending on water temperature. Because some of these Al-polymers are not cation-exchangeable (Driscoll 1984), but are HQ-MIBK extractable (Barnes 1975), they are determined as $\mathrm{Al}_{\mathrm{o}}$ by the analytical method used (Lydersen et al. 1994). The increase in $\mathrm{Al}_{\mathrm{o}}$ is therefore a confirmation of reduced cationic charge of aluminium during the initial phase of the polymerisation process. The increase in $\mathrm{Al}_{\mathrm{c}}$, calculated as the difference between $\mathrm{Al}_{\mathrm{r}}$ and total monomeric aluminium $\left(\mathrm{Al}_{\mathrm{a}}\right)$, confirm that monomeric Al-species were converted to larger, less reactive polymeric species through the channels.

\subsection{Fish mortality}

While no mortality was observed in the control fish, mortality was recorded in all Al-exposures. Mortality rates differed, however, with water composition and residence time through the channels (Fig. 2). Survival analysis showed that there were no differences in mortality between the two Al-only exposures (Weibull $\chi^{2}=$
$0.083, \mathrm{P}=0.77)$. However, there were significant differences between the chambers within the channels (Tab. 3), with the lowest mortality observed in fish exposed in the last chamber, i.e. the water with the longest residence time. Mortality increased systematically from chamber 5 to chamber 1 . The estimated survival probability in chamber 1 was only $20 \%$ of that observed in chamber 5 . There were significant differences in mortality between the Al-only exposures and the Al-exposures with base cations added (Tab. 4). Mortality was lowest in the $\mathrm{Al}+\mathrm{Na}$-exposure, and highest in the Alonly exposures. Also in the $\mathrm{Al}+\mathrm{Ca}$-exposure mortality was significantly lower than the corresponding Al-only exposure (Wald $\chi^{2}=304.89, \mathrm{P}<0.001$ ), but significantly higher than in the $\mathrm{Al}+\mathrm{Na}$-exposure (Wald $\chi^{2}=$ 58.80, $\mathrm{P}<0.001)$.

\section{DISCUSSION}

Our results confirm previous observations that the acute toxicity of aluminium under non-steady state chemical conditions is reduced with increasing age of the water, and that additions of base cations to Al-rich water reduce the toxic effect of aluminium. In addition to this, we observed that an equal increase in ionic strength due to the addition of $\mathrm{Ca}^{2+}$ and $\mathrm{Na}^{+}$, respectively, did not reduce the Al-toxicity to the same extent. Sodium seems to be the more effective base cation in reducing Al-toxicity. 
Tab. 3. Model coefficients from the survival analysis of the Al-only exposures. The model coefficients $\left(\mathrm{e}^{\beta}\right)$ with 95\% confidence intervals (c.i.) gives the survival probabilities of the Atlantic salmon in the exposure chambers within the experimental channels, compared to the survival in chamber 5 (the chamber with the lowest mortality). There were significant differences in survival probability for the fish between the chambers (Weibull $\chi^{2}=$ $350.4, \mathrm{P}<0.001)$.

\begin{tabular}{ccc}
\hline Chamber & $\mathrm{e}^{\beta}$ & $95 \%$ c.i. \\
\hline 1 & 0.197 & $0.149-0.261$ \\
2 & 0.454 & $0.345-0.598$ \\
3 & 0.576 & $0.439-0.757$ \\
4 & 0.754 & $0.565-1.004$ \\
5 & 1.000 & \\
\hline
\end{tabular}

Tab. 4. Model coefficients from the survival analysis of the four experiments (two Al-only additions, $\mathrm{Na}+\mathrm{Al}$ addition, and $\mathrm{Ca}+\mathrm{Al}$ addition). The model coefficients $\left(\mathrm{e}^{\mathrm{\beta}}\right)$ with $95 \%$ confidence intervals (c.i.) gives the survival probabilities of the Atlantic salmon in the different experiments when controlling for different survival probabilities among chambers within the different experiments). There were significant differences between the experiments (Weibull $\chi^{2}=146.5, \mathrm{P}<0.001$ ).

\begin{tabular}{lcc}
\hline \multicolumn{1}{c}{ Experiment } & $\mathrm{e}^{\beta}$ & $95 \%$ c.i. \\
\hline Al only 1 & 0.396 & $0.339-0.464$ \\
Al only 2 & 0.403 & $0.344-0.472$ \\
Al + Ca addition & 0.492 & $0.417-0.577$ \\
Al + Na addition & 1.000 & \\
\hline
\end{tabular}

True chemical equilibrium is seldom approached in natural systems like surface waters, and several toxicological studies have indicated that the acute Al-toxicity in fish may depend on the age of the Al-solution (Weatherley et al. 1991; Rosseland et al. 1992; Lydersen et al. 1994; Poléo et al. 1994; Poléo \& Bjerkely 2000). In all these studies, Al-toxicity was highest during the initial phase of Al-polymerisation which takes place right after mixing of acidic Al-rich water with circumneutral river water. After this initial phase, Al-toxicity decreased significantly with water residence time, i.e. age of the Al-polymers present in the water. In the present study we observed exactly the same feature in our Al-exposures (Fig. 2). The addition of base cations did not influence the time dependent Al-toxicity, and therefore confirm that this time dependency is important for the present understanding of acute Al-toxicity in fish. According to Poléo (1995) and Poléo \& Bjerkely (2000), the time dependent Al-toxicity under non-steady state conditions is due to the transformation of unstable monomeric aluminium to more stable polymeric Alforms when $\mathrm{pH}$ in the Al-containing water is raised. By ageing, the Al-polymers increase in size, which also means that their cationic charge decreases (Hem \& Roberson 1967). This is analytically revealed by increased concentrations of both $\mathrm{Al}_{\mathrm{o}}$ and $\mathrm{Al}_{\mathrm{c}}$, and decreased concentration of $\mathrm{Al}_{\mathrm{i}}$ under the initial Al-polym- erisation phase. Accordingly, the ability of aluminium to bind to negatively charged sites at the gill surface is reduced.

In the present study we observed that both the addition of $\mathrm{Ca}^{2+}$ and $\mathrm{Na}^{+}$had an ameliorating effect on the acute Al-toxicity in salmon. This corresponds well with the literature. It has been accepted for a long time that aqueous $\mathrm{Ca}^{2+}$ mitigates Al-toxicity in fish (Brown 1981, 1983; Playle et al. 1989). It has also been demonstrated that high concentrations of $\mathrm{Na}^{+}$in the water reduces Altoxicity (Brown 1981; Dietrich et al. 1989). The mitigating effect of aqueous $\mathrm{Ca}^{2+}$ has been attributed to its stabilising effect on the gill epithelium (reviewed by McDonald 1983). No such effect, however, is likely to be attributed to $\mathrm{Na}^{+}$, which appeared to reduce Al-toxicity as efficiently as $\mathrm{Ca}^{2+}$ (Fig. 2). However, a passive loss of ions, mainly $\mathrm{Na}^{+}$and $\mathrm{Cl}^{-}$, is to be expected in fish exposed to aluminium (reviewed by Howells et al. 1994; Gensemer \& Playle 1999). Increasing the concentration of aqueous $\mathrm{Na}^{+}$might therefore reduce passive efflux and facilitate compensatory $\mathrm{Na}^{+}$-uptake over the gill epithelium. In the present study, however, the salmon were exposed to aluminium under non-steady state conditions and at relatively high $\mathrm{pH}$ (between 5.7 and 5.9). Poléo et al. (1994) found that salmon exposed to aluminium under non-steady state conditions in the initial part of a mixing zone ( $\mathrm{pH}$ 5.6) between limed and acidic water did not suffer from ion regulatory disturbances despite enhanced mortality (75\% after $68 \mathrm{~h})$. Accordingly, Neville (1985) demonstrated that Al-toxicity in rainbow trout (Oncorhynchus mykiss) at relatively high $\mathrm{pH}$ was predominately due to hypoxia rather than ion regulatory disturbances. We might therefore assume that the salmon in our experiment, at least to some extent, was suffering from hypoxia. If so, it is reasonable to attribute the mitigating effects of $\mathrm{Ca}^{2+}$ and $\mathrm{Na}^{+}$to their contribution to water ionic strength, reducing the possibility for aluminium to interact with the gill surface.

As already mentioned, our experiments demonstrate that increasing the water ionic strength by adding $\mathrm{Na}^{+}$or $\mathrm{Ca}^{2+}$ reduces the toxic effects of aluminium. The highest effect was obtained by the addition of $\mathrm{Na}^{+}$, even though the ionic strength increase was the same in $\mathrm{Al}+\mathrm{Ca}$ and $\mathrm{Al}+\mathrm{Na}$ water. The reason for this difference could be that $\mathrm{Ca}^{2+}$ and $\mathrm{Na}^{+}$do not influence Al-chemistry in the same way. However, our Al-fractionation data reveal that there are no differences in any of the measured or calculated Al-fractions of the two treatments (Tab. 2). Furthermore, it was no difference in the saturation indexes regarding known solid Al-phases (estimated by the ALCHEMI-Version 4.0, Schecher \& Driscoll 1987, 1988). All Al-solutions seem to be close to saturation with respect to micro-crystalline gibbsite $\left(\log * \mathrm{~K}_{\mathrm{s}}=\right.$ 9.35). Another explanation is that $\mathrm{Ca}^{2+}$ and $\mathrm{Na}^{+}$mitigate the Al-toxicity by their effect on the ability for aluminium to interact with the gill surface. However, this does 
not necessarily mean that $\mathrm{Na}^{+}$more effectively ameliorate the Al-toxicity than $\mathrm{Ca}^{2+}$, because, on equivalent basis about a 1.5 times higher amount of $\mathrm{Na}^{+}$is needed to obtain the same ionic strength increase as by $\mathrm{Ca}^{2+}$. Thus, the possibility of a $\mathrm{Na}^{+}$-ion to be present near the surface of the fish gill should be higher compared to $\mathrm{Ca}^{2+}$. On the other hand, $\mathrm{Ca}^{2+}$ is a divalent ion and should therefore have better qualitative properties in the competition for cation exchange sites than the monovalent $\mathrm{Na}^{+}$, like substituting aluminium present on negatively charged sites at the gill surface. However, $\mathrm{Ca}^{2+}$ as a divalent ion will have a thicker hydration shell than $\mathrm{Na}^{+}$, which may prevent $\mathrm{Ca}^{2+}$ to come as close to the gill surface as $\mathrm{Na}^{+}$. In general cation exchangers exhibit low or moderate preference for one cation species compared to another (Bolt 1979), a preference that is further reduced when the temperature is low (Boyd 1970) as in our experiments. All together, this may explain why the Al-toxicity was lower in the $\mathrm{Al}+\mathrm{Na}$ water compared to the $\mathrm{Al}+\mathrm{Ca}$ water.

The interaction between aqueous aluminium and the gill surface seems to be of major importance for the acute toxicity of aluminium in fish (Exley et al. 1991; Poléo 1995; Exley et al. 1996; Poléo \& Bjerkely 2000). Al-accumulation and hypoxia seem to be very important for the effects of aluminium under non-steady state conditions (Poléo 1995; Poléo et al. 1995; Poléo \& Bjerkely 2000). Ionic strength should therefore play a key role for the Al-toxicity in fish because it is essential for the chemistry of all aquatic surfaces, including the fish gill.

\section{ACKNOWLEDGMENTS}

The work was supported by the Norwegian Directorate for Nature Management. In addition we want to thank Dr. Christopher Exley, Keele University, U.K. and Nina A. Rukke, University of Oslo, for reading the paper and contribute with critical comments.

\section{REFERENCES}

Atkins, P.W. 1982. General chemistry ( $2^{\text {nd }}$ ed.), Oxford University Press, Oxford: $1095 \mathrm{pp}$.

Baker, J.P., W.J. Warren-Hicks, J. Gallagher \& S.W. Christensen. 1993. Fish population losses from Adirondack lakes: The role of surface water acidity and acidification. Water Resour. Res., 29: 861-874.

Barnes, R.B. 1975. The determination of specific forms of aluminum in natural water. Chem. Geol., 15: 177- 191.

Bolt, G.H. 1979. Soil Chemistry. B. Physico-chemical models. Development in Soil Science 5B. Elsevier Scient. Publ. Company, Amsterdam: 479 pp.

Boyd, G.E. 1970. Thermal effects in ion-exchange reactions with organic exchangers: Enthalpy and heat capacity changes. In: Ion exchange in the process industries. Conference held at Imperial College of Science and Technology, London, S.W.7, July 16th-18th, 1969, with discussion that follows. Society of Chem. Industry, London: 261-269.

Brown, D.J.A. 1981. The effects of various cations on the survival of brown trout, Salmo trutta, at low pHs. J. Fish Biol., 18: 31-40.
Brown, D.J.A. 1983. Effect of calcium and aluminium concentrations on the survival of brown trout (Salmo trutta) at low pH. Bull. Environ. Contam. Toxicol., 30: 582-587.

Bua, B. \& E. Snekvik. 1972. Hatching studies with eggs from salmonids 1966-71 (in Norwegian). Vann, 7: 86-93.

Bulger, A.J., L. Lien, B.J. Cosby \& A. Henriksen. 1993. Brown trout (Salmo trutta) status and chemistry from the Norwegian thousand lake survey: Statistical analysis. Can. J. Fish. aquat. Sci., 50: 575-484.

Burrows, W.D. 1977. Aquatic aluminium: Chemistry, toxicology, and environmental prevalence. CRC Crit. Rev. Environ. Control, 7: 167-216.

Chu, B. 1967. Molecular forces: Based on the Baker lectures of Peter J.W. Debye/Benjamin Chu. Interscience Publishers, New York: $176 \mathrm{pp}$.

Cronan, C.S. \& C.L. Schofield. 1979. Aluminium leaching response to acid precipitation: Effects on high-elevation watersheds in the north-east. Science, 204: 304-306.

Dietrich, D., C.H. Schlatter, N. Blau \& M. Fisher. 1989. Aluminium and acid rain: Mitigating effects of $\mathrm{NaCl}$ on aluminium toxicity to brown trout (Salmo trutta fario) in acid water. Toxicol. Environm. Chem., 19: 17-23.

Driscoll, C.T. 1984. A procedure for the fractionation of aqueous aluminum in dilute acidic water. Intern. J. Environ. Anal. Chem., 16: 267-283.

Driscoll, C.T., J.P. Baker, J.J.Bisogni \& C.L. Schofield. 1980. Effect of aluminium speciation on fish in dilute acidified waters. Nature, 284: 161-164.

Exley, C., J.S. Chappel \& J.D. Birchall. 1991. A mechanism for acute aluminium toxicity to fish. J. Theor. Biol., 151: 417-428.

Exley, C., A.J. Wicks, R.B. Hubert \& J.D. Birchall. 1996. Kinetic constrains in acute aluminium toxicity in the rainbow trout (Oncorhynchus mykiss). J. Theor. Biol., 179: 25-31.

Fox, G.A. 1993. Failure-time analysis: Emergence, flowering, survivorship, and other waiting times. In: S.M. Scheiner \& J. Gurevitch (Eds), Design and Analysis of Ecological Experiments. Chapman \& Hall, London: 445 pp.

Gensemer, R.W. \& R.C. Playle. 1999. The bioavailability and toxicity of aluminum in aquatic environments. Crit. Rev. Environ. Sci. Technol., 29: 315-450.

Hem, J.D. \& C.E. Roberson. 1967. Form and stability of aluminum hydroxide complexes in dilute solutions. Geol. Survey Water-Supply Paper 1827-A, U.S. Government Printing Office: Washington D.C.: 55 pp.

Howells, G., T.R.K. Dalziel, J.P. Reader \& J.F. Solbe. 1994. Aluminium and freshwater fish water quality criteria. In: G. Howells (Ed.), Water quality for freshwater fish. Gordon and Breach Sci. Publ., England: 55-115.

Hutchinson, N.J., K.E. Holtze, J.R. Munro \& T.W. Pawson. 1989. Modifying effect of life stage, ionic strength and post-exposure mortality on lethality of $\mathrm{H}^{+}$and $\mathrm{Al}$ to lake trout and brook trout. Aquat. Toxicol., 15: 1-26.

Kirchner, J.W. \& E. Lydersen. 1995. Base cation depletion and potential long-term acidification of Norwegian catchments. Environ. Sci. Technol., 29: 1953-1960.

Leivestad, H., I.P. Muniz \& B.O. Rosseland. 1980. Acid stress in trout from a dilute mountain stream. In: D. Drabløs \& A. Tollan (Eds), Ecological impact of acid precipitation. SNSF-project, Sandefjord, Norway: 318-319.

Likens, G.E., C.T. Driscoll \& D.C. Buso. 1996. Long-term effects of acid rain: Responses and recovery of a forest ecosystem. Science, 272: 244-246.

Lydersen, E. 1990. The solubility and hydrolysis of aqueous aluminium hydroxides in dilute freshwaters at different temperatures. Nordic Hydrol., 21: 195-204.

Lydersen, E., S. Löfgren \& R.T. Arnesen. 2002. Metals in Scandinavian Surface Waters: Effects of acidification, Liming and Potential Re-acidification. Crit. Rev. Environ. Sci. Technol.: (in press). 
Lydersen, E., B. Salbu, A.B.S. Poléo \& I.P. Muniz. 1990. The influence of temperature on aqueous aluminium chemistry. Water Air Soil Pollut., 51: 203-215.

Lydersen, E., A.B.S. Poléo, M. Nandrup Pettersen, G. Riise, B. Salbu, F. Kroglund \& B.O. Rosseland. 1994. The importance of in situ measurements to relate toxicity and chemistry in dynamic aluminium freshwater systems. $J$. Ecol. Chem., 3: 357-265.

McDonald, D.G. 1983. The effects of $\mathrm{H}^{+}$upon gills of freshwater fish. Can. J. Zool., 61: 691-703.

Muniz, I.P. 1984. The effects of acidification on Scandinavian freshwater fish fauna. Phil. Trans. R. Soc. Lond., 305: 517-528.

Muniz, I.P. \& L. Walløe. 1990. The influence of water quality and catchment characteristics on the survival of fish populations. In: B.J. Mason (Ed.), The surface waters acidification programme. Cambridge University Press: 327-342.

Neville, C.M. 1985. Physiological responses of juvenile rainbow trout, Salmo gairdneri, to acid and aluminum - Prediction of field responses from laboratory data. Can. J. Fish. aquat. Sci., 42: 2004-2019.

Oduleye, S.O. 1975. The effects of calcium on water balance of the brown trout Salmo trutta. J. Exp. Biol., 63: 343-356.

Playle, R.C. \& C.M. Wood. 1989. Water chemistry changes in the gill micro-environment of rainbow trout: experimental observation and theory. J. Comp. Physiol. B., 159: $527-$ 537.

Poléo, A.B.S. 1995. Aluminium polymerisation - a mechanism of acute toxicity of aqueous aluminium to fish. Aquat. Toxicol., 31: 347-356.

Poléo, A.B.S. \& F. Bjerkely. 2000. Effect of unstable aluminium chemistry on Arctic char (Salvelinus alpinus). Can. J. Fish. aquat. Sci., 57: 1423-1433.

Poléo, A.B.S., S.A. Øxnevad, K. Østbye, R.A. Andersen, D.H. Oughton \& L.A. Vøllestad. 1995. Survival of crucian carp, Carassius carassius, exposed to a high low-molecular weight inorganic aluminium challenge. Aquat. Sci., 57: 350-359.

Received: May 2001

Accepted: February 2002
Poléo, A.B.S., E. Lydersen, B.O. Rosseland, F. Kroglund, B. Salbu, R. Vogt \& A. Kvellestad. 1994. Increased mortality of fish due to changing A-chemistry of mixing zones between limed streams and acid tributaries. Water Air Soil Pollut., 75: 339-351.

Rosseland, B.O., I. Blakar, F. Kroglund, A. Kvellestad, E. Lydersen, M. Staurnes, B. Salbu, R. Vogt \& A. Bulger. 1992. The mixing zone between limed and acidic river waters: Complex aluminium chemistry and extreme toxicity for salmonids. Environ. Pollut., 78: 3-8.

Schecher, W.D. \& C.T. Driscoll. 1987. An evaluation of uncertainty associated with aluminum equilibrium calculations. Water Resour. Res., 23: 525-534.

Schecher, W.D. \& C.T. Driscoll. 1988. An evaluation of the equilibrium calculations within acidification models: The effects of uncertainty in measured chemical compounds. Water Resour. Res., 24: 533-540.

Schoffeniels, E. 1967. Cellular aspects of membrane permeability. Pergamon Press, Oxford: $266 \mathrm{pp}$.

Seip, H.M., D.O. Andersen, N. Christophersen, T.J. Sullivan \& R.D. Vogt. 1989. Variations in concentrations of aqueous aluminium and other chemical species during hydrological episodes at Birkenes, southernmost Norway. $J$. Hydrol., 108: 387-405.

Sprague, J.B. 1973. The ABC's of pollutant bioassay using fish. ASTM Spec. Techn. Publ., 528: 6-30.

Steen, J.B. \& S. Stray-Pedersen. 1975. The permeability of fish gills with comments on the osmotic behaviour of cellular membranes. Acta Physiol. Scand., 95: 6-20.

Sullivan, T.J., N. Christophersen, I.P. Muniz, H.M. Seip \& P.D. Sullivan. 1986. Aqueous aluminum chemistry response to episodic increases in discharge. Nature, 323: 324-327.

Weatherley, N.S., G.P. Rutt, P. Thomas \& S.J. Ormerod. 1991. Liming acid streams: Aluminium toxicity to fish in mixing zones. Water Air Soil Pollut., 55: 345-353.

Wright, R.F. \& E. Snekvik. 1978. Acid precipitation: Chemistry and fish populations in 700 lakes in southernmost Norway. Verh. int. Ver. Limnol., 20: 765-775. 